\title{
The Northernmost Record of Champsodon nudivittis (Ogilby, 1895) in the Mediterranean Sea
}

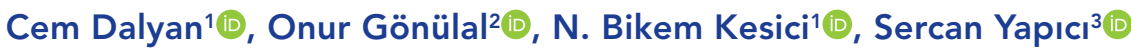

Cite this article as: Dalyan, C., Gonulal, O., Kesici, N.B., \& Yapici, S. (2021). The northernmost record of Champsodon nudivittis (Ogilby, 1895) in the Mediterranean Sea. Aquatic Sciences and Engineering, 36(2), 85-88.

ORCID IDs of the author: C.D.0000-0002-7386-5641; O.G. 0000-0002-5559-3953; N.B.K. 0000-0002-9636-1649; S.Y. 0000-0003-2288-5084

'Istanbul University, Department of Biology, Istanbul, Turkey

${ }^{2}$ Istanbul University, Faculty of Aquatic Sciences, Istanbul, Turkey

${ }^{3}$ Muğla Sıtkı Koçman University, Faculty of Fisheries, Department of Basic Sciences, Muğla, Turkey

Submitted:

27.05.2020

Revision Requested:

09.07.2020

Last Revision Received:

29.07.2020

Accepted:

09.08.2020

Online Published:

05.02.2021

Correspondence:

Cem Dalyan

E-mail:

cdalyan@istanbul.edu.tr

(C) Copyright 2021 The Author(s)

Available online at

https://dergipark.org.tr/ase

\begin{abstract}
Champsodon nudivittis (Ogilby, 1895), also known as the nakedband gaper, is distributed in the Aegean and Levantine parts of the Mediterranean Sea. It has been reported in the Mediterranean Sea as a Red Sea immigrant. The first record of the species in the Mediterranean Sea was reported in 2009 from the Levantine coasts. In this study, two individuals of nakedband gaper were captured about two months apart from the north of Gokceada Island, in the North Aegean Sea. The specimens were obtained using a trawl at depths of 100-120 m. Their total lengths were measured as 117 and $122 \mathrm{~mm}$. This report extends the distribution of C. nudivittis to the North Aegean Sea, marking its northernmost record in the Mediterranean Sea to date. Moreover, the species is the second Red Sea originated fish recorded in the area between Gokceada Island, Samothraki Island and Saros Bay. C. nudivittis is known as a predator, hence, its population density should be monitored and its impact on the ecosystem should be assessed in the North Aegean Sea.
\end{abstract}

Keywords: Champsodontidae, new record, Nakedband Gaper, North Aegean Sea, Turkey

\section{INTRODUCTION}

According to Nemeth (1994), the family Champsodontidae has one genus and thirteen species around the world. These fishes are known by their large mouths, laterally compressed bodies and small denticulate scales. They are originated from the Indo-Pacific oceans and their populations are concentrated around the tropical zone. Among them, Champsodon nudivittis (Ogilby 1895), C. vorax Günther, 1867 and C. capensis Regan, 1908 were reported in the Mediterranean Sea as Red Sea immigrants (Bariche, 2010; Çiçek \& Bilecenoğlu, 2009; Dalyan et al., 2012). Finally, Stern et al. (2020) asserted that all of the recorded individuals belonged to $C$. nudivittis in the light of morphological and genetic data in the Mediterranean Sea. The Aegean and Levantine Seas represent the expanded range of the species in the Mediterranean Sea (Figure 1). All Mediterranean records of the nakedband gaper are listed in (Table 1).
Champsodon nudivittis is native to the Indo-West Pacific, and found in Madagascar, Indonesia, the Philippines, Australia and the Red Sea (Froese \& Pauly, 2020; Goren et al., 2012). It is a bathypelagic species and found at depths between 0 - 716 m (Dalyan et al., 2012; Froese \& Pauly, 2020). It is known as the deepest invasive fish that was recorded at a depth of $716 \mathrm{~m}$, in the Mediterranean Sea (Dalyan et al., 2012).

Previously, the species has reached up to the Central Aegean Sea (Kebapçıoglu \& Dereli, 2016). And, the present report is related to the first record of C. nudivittis in the North Aegean Sea. Besides Lagocephalus sceleratus (Gmelin, 1789), which has also been recorded in this area (Katsanevakis et al., 2014), this report provides the second record of Red Sea immigrant fish species in the area between Gokceada Island, Samothraki Island and Saros Bay, which is a special zone due to its high biodiversity. 


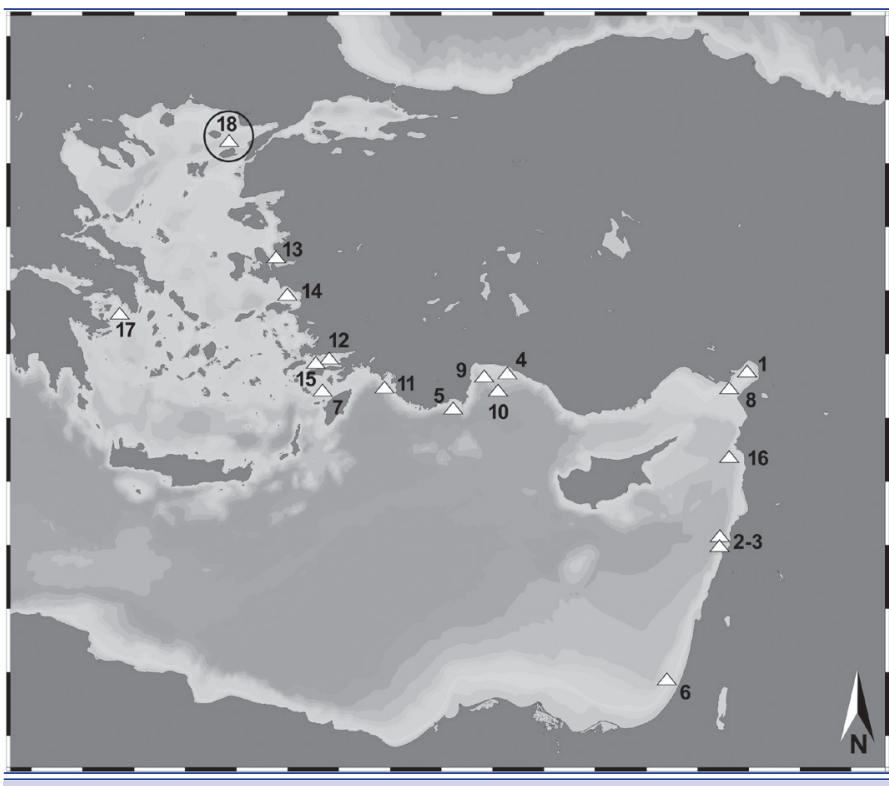

Figure 1. Distribution map of C. nudivittis in the Mediterranean Sea.

\section{MATERIALS AND METHODS}

On 12 November, 2019 and 5 January, 2020, two specimens of C. nudivittis were captured by trawl in the north of Gokceada Island, Turkey, in the North Aegean Sea at depths of 100-120 m (on a sandy-muddy bottom). The first individual was found at coordinates between $40^{\circ} 14^{\prime} 10^{\prime \prime} \mathrm{N} ; 25^{\circ} 49^{\prime} 54^{\prime \prime} \mathrm{N}$ and $40^{\circ} 13^{\prime} 58^{\prime \prime} \mathrm{N} ; 25^{\circ} 48^{\prime} 06^{\prime \prime} \mathrm{E}$. The coordinate of the second specimen could not be recorded. The specimens were caught by the commercial vessel UĞUR REIS$3(17 \mathrm{~m}, 500 \mathrm{HP})$. Morphological features were measured on the individuals using a digital caliper (nearest $0.01 \mathrm{~mm}$ ).

The specimens were identified as C. nudivittis following Nemeth (1994) and Stern et al. (2020). The individuals were preserved in $50 \%$ ethanol solution and stored in the Istanbul University Science Faculty, Hydrobiology Museum (IUSHM 2019-1414, IUSHM 2020-1419).

\section{RESULTS AND DISCUSSION}

The captured specimens of the nakedband gaper, C. nudivittis, were 122 and $117 \mathrm{~mm}$ total length and they weighed 10 and $9 \mathrm{~g}$ respectively (Table 2 ). The specimens had the following features: Head length 3.6-3.7 times and body width 6.5-6.8 times the standard length, SL. Snout length 3.6-4.0 times and eye diameter 4.8-4.6 times the head length, HL. The body was well compressed. The maxilla extended beyond the eye, the chin was without scales and covered with melanophore spots. The breast was scaled.

All metric and meristic data, forming of the specialized scales, and color of the features individuals were consistent with Nemeth (1994) and Stern et al. (2020) and indicated the identification to be $C$. nudivittis (Figure 2). It is distinguished from its congenerics by having no scales on its chin while it has a restricted or wide scaled area on the pectoral. In the last decade, C. nudivittis have \begin{tabular}{ll}
\hline Table 1. & $\begin{array}{l}\text { Records of C. nudivittis in the Mediterranean } \\
\text { Sea. }\end{array}$
\end{tabular}

\begin{tabular}{|c|c|c|c|}
\hline & Year & Locality & References \\
\hline 1 & 2009 & $\begin{array}{l}\text { Iskenderun Bay (Turkey) } \\
\text { / Levantine Sea }\end{array}$ & $\begin{array}{c}\text { Çiçek \& Bilecenoğ- } \\
\text { lu, } 2009\end{array}$ \\
\hline 2 & 2010 & $\begin{array}{l}\text { Coast of Baotrun (Lüb- } \\
\text { nan) / Levantine Sea }\end{array}$ & Bariche, 2010 \\
\hline 3 & 2011 & $\begin{array}{l}\text { Coast of Baotrun (Lüb- } \\
\text { nan) / Levantine Sea }\end{array}$ & Bariche, 2011 \\
\hline 4 & 2011 & $\begin{array}{l}\text { Gulf of Antalya (Turkey) } \\
\text { / Levantine Sea }\end{array}$ & Gökoğlu et al., 2011 \\
\hline 5 & 2011 & $\begin{array}{l}\text { Finike Bay (Turkey) / } \\
\text { Levantine Sea }\end{array}$ & $\begin{array}{l}\text { Erguden \& Turan, } \\
2011\end{array}$ \\
\hline 6 & 2011 & $\begin{array}{l}\text { off Ashdod (Israel) / } \\
\text { Levantine Sea }\end{array}$ & Goren et al., 2011 \\
\hline 7 & 2012 & $\begin{array}{l}\text { North of Rodos } \\
\text { (Greece) / Aegean Sea }\end{array}$ & $\begin{array}{c}\text { Kalogirou and Corsi- } \\
\text { ni-Foka, } 2012\end{array}$ \\
\hline 8 & 2012 & $\begin{array}{l}\text { Iskenderun Bay (Turkey) } \\
\text { / Levantine Sea }\end{array}$ & Dalyan et al., 2012 \\
\hline 9 & 2013 & $\begin{array}{l}\text { Gulf of Antalya (Turkey) } \\
\text { / Levantine Sea }\end{array}$ & $\begin{array}{c}\text { Gökoğlu \& Özvarol, } \\
2013\end{array}$ \\
\hline 10 & 2013 & $\begin{array}{l}\text { Gulf of Antalya (Turkey) } \\
\text { / Levantine Sea }\end{array}$ & $\begin{array}{c}\text { Gökoğlu \& Özvarol, } \\
2013\end{array}$ \\
\hline 11 & 2014 & $\begin{array}{l}\text { Ekincik and Fethiye Bay } \\
\text { (Turkey) / Aegean Sea }\end{array}$ & Filiz et al., 2014 \\
\hline 12 & 2015 & $\begin{array}{l}\text { Gokova Bay (Turkey) / } \\
\text { Aegean Sea }\end{array}$ & Akyol \& Ünal, 2015 \\
\hline 13 & 2015 & $\begin{array}{l}\text { Izmir Bay (Turkey) / } \\
\text { Aegean Sea }\end{array}$ & Aydın \& Akyol, 2015 \\
\hline 14 & 2016 & $\begin{array}{l}\text { Kusadasi Bay (Turkey) / } \\
\text { Aegean Sea }\end{array}$ & $\begin{array}{c}\text { Kebapcioglu \& Der- } \\
\text { eli, } 2016\end{array}$ \\
\hline 15 & 2016 & $\begin{array}{l}\text { Gokova Bay (Turkey) / } \\
\text { Aegean Sea }\end{array}$ & Yapıcı et al., 2016 \\
\hline 16 & 2017 & $\begin{array}{l}\text { off Jableh (Syria) / Le- } \\
\text { vantine Sea }\end{array}$ & Ali et al., 2017 \\
\hline 17 & 2019 & $\begin{array}{l}\text { Saronikos Gulf (Greece) } \\
\text { / Aegean Sea }\end{array}$ & $\begin{array}{l}\text { Kousteni \& Chris- } \\
\text { tidis, } 2019\end{array}$ \\
\hline 18 & 2020 & $\begin{array}{l}\text { North of Gokceada } \\
\text { Island (Turkey) / Aegean } \\
\text { Sea }\end{array}$ & Present study \\
\hline
\end{tabular}

appeared to be the main subject of many articles with their high invasive characteristic in the Eastern Mediterranean Sea, and the common view is that the species entered the Mediterranean through the Suez Canal (Bariche, 2010; Çiçek \& Bilecenoğlu, 2009; Dalyan et al., 2012). Moreover, C. nudivittis were reported in the Red Sea (Goren et al., 2014).

It is not surprising that the species that reach the maximum age early and have an r-selected life history, have opportunistic characters and will be invasive in their newly arrived areas. The maximum age of $C$. nudivittis is determined as two (Yağlığlu et al., 2014) and four (Demirci et al., 2016) in the Mediterranean. This can be considered as an advantage that strengthens the invasive character of the fish. 
Table 2. Morphometric and meristic features of $C$. nudivittis in the north of Gokceada Island.

\begin{tabular}{lcc}
\hline Measurement & Spc. 1 & Spc. 2 \\
\hline Total length $(\mathrm{mm})$ & 122 & 117 \\
Standard length $(\mathrm{mm})$ & 104 & 101 \\
Body depth $(\mathrm{mm})$ & 16 & 14.9 \\
Body width $(\mathrm{mm})$ & 11 & 10.5 \\
Head length $(\mathrm{mm})$ & 29 & 27.4 \\
Snout length $(\mathrm{mm})$ & 8 & 6.9 \\
Eye diameter $(\mathrm{mm})$ & 6 & 5.9 \\
Standard length/Head length & 3.6 & 3.7 \\
Standard length/Body depth & 6.5 & 6.8 \\
Head length/Snout length & 3.6 & 4.0 \\
Head length/Eye diameter & 4.8 & 4.6 \\
& & \\
D1 & $\mathrm{V}$ & $\mathrm{V}$ \\
D2 & $19(1)$ & 19 \\
A & $17(1)$ & 18 \\
P & 13 & 13
\end{tabular}

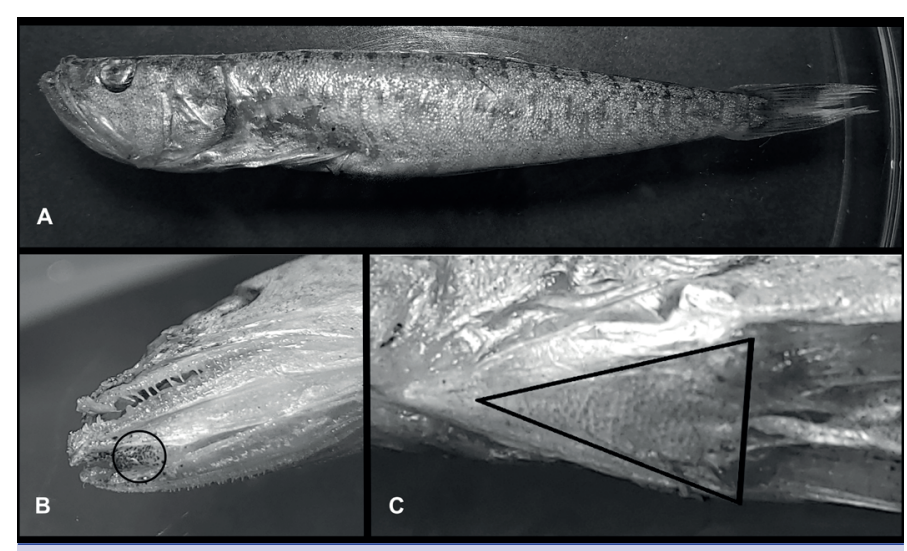

Figure 2. The whole body (A), chin (B) and breast $(C)$ of the sampled specimen of $C$. nudivittis from the northwest of Gökçeada Island, Turkey.

\section{CONCLUSION}

This study provides the northernmost record of C. nudivittis in the Mediterranean Sea it is also the second documented Red Sea immigrant fish species to has been found in the area between Gokceada Island, Samothraki Island and Saros Bay. The population density of the fish should be monitored in the North Aegean Sea due to its high trophic level; besides its impact on the ecosystem should be assessed.

Conflict of interests: The authors have no conflicts of interest to declare.

Ethics committee approval: This study was conducted in accordance with ethics committee procedures of animal experiments.

Funding: This study was supported by the Research Fund of Istanbul University (Project No. FBA-2017-23597).
Acknowledgments: Authors wish to thank the crew of the UĞUR REIS-3 for their help with the samplings.

\section{Disclosure: -}

\section{REFERENCES}

Akyol, O. \& Ünal, V. (2015). Occurrence of the Indo-Pacific Champsodon nudivittis (Perciformes, Champsodontidae) in the Bay of Gökova (Southern Aegean Sea, Turkey). Turkish Journal of Fisheries and Aquatic Sciences, 15(1), 187-190. [CrossRef]

Ali, M., Saad, A., Jabour, R., Rafrafi-Nouira, S. \& Capapé, C. (2017). First record of nakedband gaper Champsodon nudivittis (Osteichthyes: Champsodontidae) off the Syrian Coast (Eastern Mediterranean). Journal of Ichthyology, 57, 161-163. [CrossRef]

Aydın, i. \& Akyol, O. (2015). First Record of an Indo-Pacific Gaper, Champsodon vorax (Actinopterygii: Perciformes: Champsodontidae), from the Aegean Sea, Turkey. Acta Ichthyologica Et Piscatoria, 45(2), 207-209. [CrossRef]

Bariche, M. (2010). Champsodon vorax (Teleostei: Champsodontidae), a new alien fish in the Mediterranean. Aqua International Journal of Ichthyology, 16(4), 197-200.

Bariche, M. (2011). First record of the cube boxfish Ostracion cubicus (Ostraciidae) and additional records of Champsodon vorax (Champsodontidae), from the Mediterranean. Aqua, International Journal of Ichthyology, 17(4), 181-184.

Çiçek, E. \& Bilecenoğlu, M. (2009). A new alien fish in the Mediterranean Sea: Champsodonnudivittis(Actinopterygii:Perciformes: Champsodontidae). Acta Ichthyologica et Piscatoria, 39(1), 67-69. [CrossRef]

Dalyan, C., Yemişken, E. \& Eryılmaz, L. (2012). A new record of gaper (Champsodon capensis Regan, 1908) in the Mediterranean Sea. Journal of Applied Ichthyology, 28(5), 834-835. [CrossRef]

Ergüden, D. \& Turan, C. (2011). Occurrence of the nakedband gaper, Champsodon nudivittis (Ogilby, 1895) (Osteichthyes: Champsodontidae), in Finike Bay, eastern Mediterranean, Turkey. Journal of Applied Ichthyology, 27(6), 1397-1398. [CrossRef]

Filiz, H., Akçimar, S.C. \& Irmak, E. (2014). Occurrence, length-weight and length-length relationships of Champsodon nudivittis (Ogilby, 1895) in the Aegean Sea. Journal of Applied Ichthyology, 30(2), 415-417. [CrossRef]

Froese, R, \& Pauly, D. (2020). FishBase, World Wide Web electronic publication, Available from: http://www.fishbase.org, (03/2020).

Gökoğlu, M., Ünlüsayın, M., Balcı, B. A., Özvarol, Y. \& Çolak, H. (2011). Two alien fish in the Gulf of Antalya: Apogon queketti Gilchrist, 1903 (Apogonidae) and Champsodon nudivittis (Ogilby, 1895) (Champsodontidae). Zoology in the Middle East, 54(1), 138-140. [CrossRef]

Gökoğlu, M. \& Özvarol, Y. (2013). Additional Records of Champsodon vorax and Champsodon capensis (Actinopterygii: Perciformes: Champsodontidae) From The Eastern Mediterranean Sea. Acta Ichthyologica Et Piscatoria, 43(1), 79-82. [CrossRef]

Gören, M., Stern, N., Galil, B. S. \& Diamant, A. (2011). On the occurrence of the Indo-Pacific Champsodon nudivittis (Ogilby, 1985) (Perciformes, Champsodontidae) from the Mediterranean coast of Israel, and the presence of the species in the Red Sea. Aquatic Invasions 6, 115-117. [CrossRef]

Gören, M., Ganga, U. \& Jinesh, T. P. (2014). Champsodon vorax and Champsodon nudivittis, two new records from the north-eastern Arabian Sea (Perciformes, Champsodontidae). Marine Biodiversity Records, 7, 1-4. [CrossRef]

Kalogirou, S. \& Corsini-Foka, M. (2012). First record of the Indo-Pacific Champsodon nudivittis (Ogilby, 1895) (Perciformes, Champsodontidae) in the Aegean waters (eastern Mediterranean Sea). Biolnvasions Records, 1, 229-233. [CrossRef] 
Katsanevakis, S., Ammar, I., Acar, U., Bekas, P., Balci, B. A., Belmonte, M., Chintiroglou, C. C., Consoli, P., Dimiza, M., Fryganiotis, K., Gerovasileiou, V., Gnisci, V., Gulsahin, N., Hoffman, R., Issaris, Y., Izquierdo-Gomez, D., Izquierdo-Munoz, A., Kavadas, S., Koehler, L., Konstantinidis, E., Mazza, G., Nowell, G., Onal, U., Ozen, M.R., Pafilis, P., Pastore, M., Perdikaris, C., Poursanidis, D., Prato, E., Russo, F., Sicuro, B., Tarkan, A.N., Thessalou-Legaki, M., Tiralongo, F., Triantaphyllou, M., Tsiamis, K., Tuncer, S., Turan, C., Turker, A., \& Yapici, S. (2014). "New Mediterranean Biodiversity Records (October, 2014)". Mediterranean Marine Science, 15, 675-695. [CrossRef]

Kebapçıŏlu, T. \& Dereli, H. (2016). First record of gaper (Champsodon capensis Regan, 1908) in the Aegean Sea. Mediterranean Marine Science, 17(3), 794-821.

Kousteni, V. \& Christidis, G. (2019). Westward range expansion of the Indo-Pacific nakedband gaper Champsodon nudivittis (Ogilby, 1895) in Saronikos Gulf, Greece. Biolnvasions Records, 8(1), 167-174. [CrossRef]

Nemeth, D. (1994). Systematics and distribution of fishes of the family Champsodontidae (Teleostei: Perciformes), with descriptions of three new species. Copeia, 2, 347-371. [CrossRef]

Yapici, S., Fricke, R. \& Filiz, H. (2016). Champsodontids at the gates: first record of Champsodon vorax Günther, 1867 from the Aegean Sea (Teleostei: Champsodontidae). Journal of Applied Ichthyology, 32(1), 120-122. [CrossRef]

Yemişken, E., Dalyan, C. \& Eryılmaz, L. (2014). Catch and discardfish species of trawl fisheries in the Iskenderun Bay (Northeastern Mediterranean) with emphasis on lessepsian and chondricthyan species. Mediterranean Marine Science, 15(2), 380-389. [CrossRef] 